\title{
ANALISA FAKTOR OSEANOGRAFI DALAM MENDUKUNG BUDIDAYA RUMPUT LAUT Kappaphycus alvarezii DI PERAIRAN PULAU SEMBILAN KABUPATEN SINJAI
}

Analysis Of Oceanographic Factors In Support of Kappaphycus alvarezii Seaweed In The Waters Of The Islands of Nine Sinjai District

\author{
Sri Indriyani ${ }^{1}$, Hadijah $^{2}$, Erni Indrwati $^{2}$ \\ ${ }^{1}$ Dinas Kelautan dan Perikanan Kabupaten Sinjai \\ ${ }^{2}$ Program Studi Budidaya Perairan Program Pascasarjana Universitas Bosowa
}

Email : indriyaniamir4@gmail.com

Diterima : 08 Agustus 2019

Dipublikasikan : 09 Desember 2019

\begin{abstract}
ABSTRAK
Penelitian ini bertujuan untuk mengetahui faktor oseanografi dan tingkat kesesuaian lokasi perairan Pulau Sembilan dalam mendukung budidaya rumput laut Kappaphycus alvarezii. Penelitian ini dilaksanakan pada Bulan Juni - Oktober 2019. Penentuan lokasi budidaya rumput laut, dipilih berdasarkan kriteria sengaja ( purposive sampling ). Hasil penelitian memperlihatkan kisaran nilai: a) Parameter fisika terdiri atas: (1) arus $5-30 \mathrm{~cm} / \mathrm{dtk}$, (2) suhu $28,7-32{ }^{\circ} \mathrm{C}$ (3) kedalaman sebesar $2 \mathrm{~m}-10 \mathrm{~m}$, (4) kecerahan $1 \mathrm{~m}-3,5 \mathrm{~m}$, (5) substrat dasar perairan karang, berpasir (b) Parameter Kimia terdiri dari: (1) salinitas perairan $30 \mathrm{ppt}-32,8 \mathrm{ppt}$, (2) pH 7,37 - 9,31 (3) oksigen terlarut 4,16 - 11,08 mg/l (4) carbon dioksida 2 - $6 \mathrm{mg} / \mathrm{l}$ (5) fosfat $0,044 \mathrm{mg} / \mathrm{l}-1,185 \mathrm{mg} / \mathrm{l}$, (6) nitrat 0,046- mg/l- 1,104 mg/l. c) Parameter biologi terdiri atas: organisme pengganggu berupa ikan dan lumut. Hasil skoring menunjukkan untuk ketiga stasiun dapat dilakukan kegiatan budidaya Kappaphycus alvarezii yaitu pada Pulau Kambuno, Batanglampe dan Kodingare.
\end{abstract}

Kata Kunci: Budidaya; Kappaphycus alvarezii; oseanografi; Rumput Laut: Sinjai.

\section{ABSTRACT}

This study aims to determine oceanographic factors and the suitability of the waters of the nine islands in supporting seaweed cultivation Kapphaphycus alvarezii. The research was conducted in June-october 2019. Determination of a proposed seaweed cultivation area, was conducted bu using conformity criterias based on the results matrix scoring and weighting. The results showed a range of values: a) physical parameters consist of (1) the flow velocity of $5 \mathrm{~cm} / \mathrm{s}$ to $30 \mathrm{c} \mathrm{m} / \mathrm{s}(2)$ water temperature $28,7^{\circ} \mathrm{C}$ to $32^{\circ} \mathrm{C}$, (3) the depth of 2 $m$ to $10 \mathrm{~m}$, (4) brightness of $1 \mathrm{~m}$ to 3,5 $\mathrm{m}$, (5) water bottom material types include: sand and coral, b) Chemical parameters consist of: (1) salinity waters $30 \mathrm{ppt}$ to $32.8 \mathrm{ppt}$, (2) pH 7,37 to 9.31, (3) dissolved oxygen 4,16 to 11,08 ppm (4) carbondioksida 2 to 6 ppm ,(5) phosphate $0.044 \mathrm{mg} / \mathrm{l}$ to $1.104 \mathrm{mg} / \mathrm{l}$, (4) nitrate 0,046 $\mathrm{mg} / \mathrm{l}$ to $1.104 \mathrm{mg} / \mathrm{l}$. c) Biological parameters consist of disturbing organism such as fish and mosses. Scoring results show for the three station can be used for farming Kappaphycus alvarezii activities in the islands Kambuno, Kodingare and Batanglampe.

Keywords: Aquaqulture; Kappaphycus alvarezii;oceanografi: seaweed: Sinjai

\section{PENDAHULUAN}

Kabupaten Sinjai terletak di jazirah Selatan bagian Timur Propinsi Sulawesi Selatan dan berada pada posisi $5^{\circ} 19^{\prime} 30^{\prime \prime}$ sampai $5^{\circ} 36^{\prime} 47^{\prime \prime}$ Lintang Selatan dan $119^{\circ} 48^{\prime} 30^{\prime \prime}$ sampai $120^{\circ}$ 0' 0" Bujur Timur. Luas wilayah mencakup $819,96 \mathrm{Km}^{2}$ atau $1,29 \%$ dari luas wilayah daratan Sulawesi Selatan. Secara geografis Kabupaten Sinjai terdiri dari wilayah pesisir, dataran rendah dan dataran tinggi. Wilayah pesisir Kabupaten Sinjai dengan panjang garis pantai utama $\pm 31 \mathrm{~km}$, dan memiliki sembilan pulau yang masuk ke wilayah kecamatan Pulau Sembilan dengan panjang garis pantai $\pm 14 \mathrm{~km}$.

Perairan Pulau Sembilan merupakan daerah potensial dan strategis untuk pengembangan budidaya laut, hal ini dikarenakan wilayah ini berada pada bibir Teluk Bone yang dilalui arus dari Laut Flores menuju Teluk Bone demikian pula sebaliknya dengan potensi yang sangat besar $( \pm 3000$ ha). Salah satu pengembangan budidaya yang dilakukan oleh masyarakat Pulau Sembilan adalah budidaya rumput laut.

Rumput laut atau seaweed merupakan salah satu tumbuhan laut yang tergolong dalam makroalga benthik atau benthic algae yang hidupnya melekat di dasar perairan. Tanaman ini tidak bisa dibedakan antara bagian akar, batang, dan daun, sehingga bagian tumbuhan tersebut disebut thallus, oleh karena itu rumput laut digolongkan tumbuhan tingkat rendah.
Salah satu jenis rumput laut yang sangat diminati untuk dibudidayakan adalah adalah jenis Kappaphycus alvarezii, karena mempunyai harga yang cukup tinggi dibanding rumput laut jenis lainnya. Jenis rumput laut ini merupakan penghasil karaginan jenis kappa. Karaginan yang dihasilkan dimanfaatkan pada industri makanan, industri kosmetik, obat-obatan, tekstil, cat dan sebagai materi dasar dari aromatic diffuser (Ghufron, 2010).

Namun keberhasilan kegiatan budidaya rumput laut sangat ditentukan dari pemilihan lokasi yang tepat. Parameter lingkungan yang menjadi penentu lokasi yang tepat untuk budidaya rumput laut adalah kondisi lingkungan fisik yang meliputi: kecepatan arus, suhu, kedalaman, kecerahan, substrat dan lingkungan kimia yaiyu: salinitas, $\mathrm{pH}, \mathrm{CO} 2$, oksigen terlarut, nitrat dan fosfat, serta biologi yang meliputi hama dan penyakit. Sujatmiko (2017) menyatakan bahwa lahan budidaya yang cocok terutama sangat ditentukan oleh kondisi ekologis yang meliputi kondisi lingkungan fisik, kimia dan biologi.

Berdasarkan studi referensi dan hasil penelitian yang ada, maka peneliti tertarik untuk melakukan analisa factor oseanografi berdasarkan aspek fisika, kimia dan biologi dalam mendukung budidaya rumput laut Kappaphycus alvarezii di perairan Pulau Sembilan Kabupaten Sinjai. 


\section{METODE PENELITIAN}

Metode penelitian yang dilakukan adalah pengumpulan data primer yang dilakukan dengan pengukuran langsung parameter fisika, kimia dan biologi di lapangan, analisis kualitas air di lakukan di Laboratorium Oseanografi Balai Penelitian dan Pengembangan Budidaya Air Payau/ BPPBAB Kabupaten Maros.

Lokasi penelitian meliputi perairan Pulau Sembilan Kabupaten Sinjai yang terletak pada $120^{\circ} 23^{\prime} 10,97^{\prime}-120^{\prime}$ $25^{\prime} 38,91^{\prime \prime}$ Bujur Timur dan $05^{\circ} 07^{\prime} 17,30^{\prime}-05^{\circ} 07^{\prime} 31,30^{\prime}$ Lintang Selatan. dan titik stasiun digambarkan pada peta wilayah pengambilan sampel (Gambar 1).

Alat-alat yang digunakan pada penelitian ini yaitu: perahu motor, Global Positioning System (GPS), layanglayang arus, stopwatch, sedimen grab, secchi disk, Water Quality Checker (WQC), botol sampel, cool box, kompas, kamera dan alat tulis menulis.

Penentuan titik pengambilan sampel terdiri atas 3 (tiga) stasiun yang dipilih secara sengaja (purposive sampling), dimana sebelumnya dilakukan observasi lokasi untuk mendapatkan gambaran umum mengenai lokasi lokasi yang nantinya akan dijadikan sebagai titik pengambilan sampel di perairan Pulau Sembilan. Pengambilan sampel di tiap stasiun dilakukan sebanyak (5) lima kali. Adapun stasiun pengambilan sampel tersebut yaitu:

$>\quad$ Stasiun I terletak di Pulau Kambuno

$>$ Stasiun II terletak di Pulau Batanglampe

$>\quad$ Stasiun III terletak di Pulau Kodingare

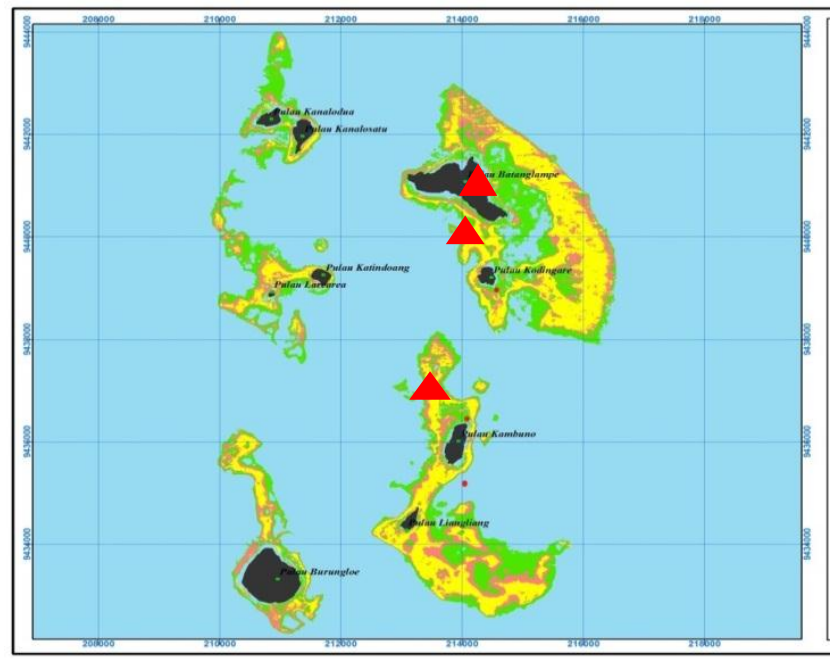

Gambar 1. Peta Stasiun Penelitian di Perairan Pulau Sembilan.

Pengambilan sampel parameter fisika, kimia dan biologi di perairan dilakukan sebanyak 5 (lima) kali. Sampel yang dapat diukur secara in situ dilakukan pengukuran secara in situ dan sampel yang perlu dianalisis lebih lanjut, dibawa ke Laboratorium Oseanografi Balai Penelitian dan Pengembangan Budidaya Air Payau/ BPPBAB Kabupaten Maros.

Parameter kualitas perairan yang diukur terbagi atas 3 yaitu:

Parameter Fisika, variabel yang diukur meliputi:

- Kecepatan arus, pengukuran dilakukan dengan memasukkan alat current meter pada kedalaman $\pm 30 \mathrm{~cm}$ dari permukaan air. Untuk memperoleh nilai kecepatan arus maka dihitung sampai sejauh mana alat tersebut dibawa oleh arus. Standar yang digunakan adalah tali yang diikatkan pada current meter.

- Suhu perairan, suhu perairan diukur dengan menggunakan Water Quality Checker tipe Horiba U10A di setiap titik sampling.

- Kecerahan, pengambilan data kecerahan perairan dilakukan dengan menggunakan alat sechii disc pada setiap titik sampling.

- Kedalaman, pengukuran kedalaman perairan dilakukan dengan menggunakan tali tambang yang ada pada sedimen grab yang sudah diberi tanda untuk tiap meternya.

- Material dasar perairan, pengambilan sampel dilakukan dengan menggunakan alat sedimen grab, substrat dimasukkan dalam kantong sampel untuk kemudian dianalisis di laboratorium.

Parameter Kimia, variabel yang diukur meliputi:

- Salinitas, pengukuran derajat keasaman perairan/salinitas dilakukan dengan menggunakan water quality checker tipe Horiba U10A.

- $\mathrm{pH}, \mathrm{pH}$ perairan diukur dengan menggunakan water quality checker tipe Horiba U10A.

- Oksigen terlarut, pengukuran oksigen terlarut pada tiap titik sampling dengan menggunakan water quality checker tipe Horiba U10A.

- Fosfat dan Nitrat, untuk mengetahui kandungan fosfat dan nitrat dilakukan dengan mengambil sampel air laut dan dimasukkan ke dalam boto; sampel, lalu dimasukkan dalam cool box kemudian dibawa ke laboratorium untuk dianalisis.

> Parameter Biologi, dilakukan dengan pengamatan langsung/ visual dan wawancara. Variabel yang diamati berupa hama pengganggu (ikan pemangsa dan organisme penempel).

Data yang akan digunakan dalam rencana penelitian ini adalah data primer dan data sekunder. Data primer meliputi; data yang di peroleh dari pengukuran parameter fisika, kimia, dan biologi. Sedangkan data sekunder meliputi data yang diperoleh dari hasil penelitian terdahulu, literatur-literatur penunjang dan beberapa referensi lainnya yang berhubungan dengan lokasi penelitian.

Pengolahan data dilakukan dengan menghitung kecepatan arus yang diukur dengan persamaan Kreyzing (1993, dalam Rasyid, 2005):

$$
\mathbf{V}=\mathbf{s} / \mathbf{t}
$$

dimana: $\mathrm{V}=$ Kecepatan arus $(\mathrm{m} /$ detik$)$

$$
\begin{aligned}
& \mathrm{s}=\operatorname{Jarak}(\mathrm{m}) \\
& \mathrm{t}=\text { Waktu (detik) }
\end{aligned}
$$

Analisis kesesuaian perairan untuk budidaya rumput laut dilakukan dengan membuat matriks kesesuaian perairan untuk parameter fisika, kimia dan biologi. Penyusunan matrik kesesuaian perairan merupakan dasar dari analisis keruangan melalui skoring dan faktor pembobot. Hasil skoring dan pembobotan di evaluasi 
sehingga didapatkan kategori kesesuaian yang menggambarkan tingkat kecocokan dari suatu lokasi untuk penggunaan tertentu. Tingkat kesesuaian dibagi atas tiga kelas, yaitu:

> Kelas S1, sangat sesuai (Highly Suitable), diberi skor 3 (tiga),

> Kelas S2; sesuai (Marginally Suitable), diberi skor 2 (dua), dan

$>\quad$ Kelas S3; tidak seuai (Not Suitable), diberi skor 1 (satu).

Nilai skor diperoleh dengan menggunakan persamaan Utoyo et al (2000) sebagai berikut:

\section{Nilai skor $=\Sigma$ Skor $\mathbf{x}$ Bobot}

Data yang diperoleh dilapangan, diolah dan dianalisis untuk menentukan kelayakan lokasi budidaya rumput laut Kappaphycus alvarezii.

Setelah mengetahui nilai skor untuk setiap parameter pada setiap satasiun, maka dilakukan dengan penilaian hasil evaluasi dengan menggunakan Tabel 1 untuk menentukan apakah lokasi tersebut sangat sesuai (S1), sesuai (S2) dan tidak sesuai (N) untuk lokasi budidadaya rumput laut Kappaphycus alvarezii. Penilaian skor hasil evaluasi diperoleh dengan persamaan yang dikemukakan oleh Nurdin et al (2012) adalah sebagai berikut:

$$
C i=\frac{\text { Bobot } \boldsymbol{m a x} .- \text { bobot } \boldsymbol{m i n} .}{n}
$$

Dimana: $\mathrm{Ci}=$ Range antar kelas

$$
\mathrm{n}=\text { Jumlah kelas yang direncanakan }
$$

Tabel 1. Sistem penilaian untuk kesesuaian perairan budidaya rumput laut adalah sebagai berikut:

\begin{tabular}{c|c|l}
\hline Kisaran Nilai & Kelas & \multicolumn{1}{|c}{ Penilaian hasil Evaluasi } \\
\hline \multirow{2}{*}{$68-87$} & Sesuai & Daerah ini tidak mempunyai \\
& (S1) & Pembatas (penghambat) yang berarti \\
& Cukup & Daerah ini mempunyai pembatas \\
$48-67$ & sesuai & (pengahambat) \\
& (S2) & yang cukup berarti \\
& Tidak & Daerah ini mempunyai pembatas \\
$27-47$ & sesuai & (penghambat) dengan tingkat sangat \\
& (N) & berat \\
\hline
\end{tabular}

Sumber : Nurdin et al (2012)

\section{HASIL DAN PEMBAHASAN}

Hasil pengukuran parameter fisika, kimia dan biologi serta kesesuaian lahan dalam mendukung budidaya rumput laut Kappaphycus alvarezii di perairan Pulau Sembilan dengan tiga titik yaitu stasiun I (Pulau Kambuno), stasiun II (Pulau Batang lampe) dan stasiun III (Pulau Kodingare) dapat dilihat pada tabel berikut:

Tabel 2. Hasil Pengukuran Parameter Fisika, Kimia dan

Biologi serta Kesesuaian Lahan pada Stasiun Penelitian di Perairan Pulau Sembilan.

\begin{tabular}{l|c|c|c}
\hline \multicolumn{1}{c|}{ Variabel } & Stasiun & Stasiun & Stasiun \\
& I & II & III \\
\hline Arus $(\mathrm{cm} / \mathrm{s})$ & $10-30$ & $5-25$ & $10-25$ \\
Suhu $\left({ }^{\circ} \mathrm{C}\right)$ & $28,9-32$ & $28,7-31$ & $28,7-30$ \\
Kecerahan (m) & $1-3$ & $1,50-3$ & $1-3,5$ \\
Kedalaman (m) & $1,5-8,5$ & $2-8$ & $1-6,5$ \\
Substrat & Karang & Karang & Karang \\
Salinitas (ppt) & $30,0-31,6$ & $31,4-32,8$ & $31,0-32,5$ \\
pH & $7,37-9,25$ & $7,6-8,77$ & $7,87-9,31$ \\
DO (mg/l) & $4,16-11,1$ & $4,48-8,83$ & $4,8-10,3$ \\
COD (mg/l) & $4-24$ & $4-24$ & $2-36$ \\
\end{tabular}

\begin{tabular}{l|c|c|c} 
Fosfat (mg/l) & $0,063-$ & $0,044-0,097$ & $0,046-0,096$ \\
& 0,067 & & \\
Nitrat (mg/l) & $0,053-$ & $0,046-0,558$ & $0,056-1,104$ \\
& 0,146 & & \\
$\mathrm{~Pb}(\mathrm{mg} / \mathrm{l})$ & 0,003 & 0,002 & 0,002 \\
$\mathrm{Cd}(\mathrm{mg} / \mathrm{l})$ & 0,006 & 0,005 & 0,005 \\
$\mathrm{Hama}$ & Ikan dan & Ikan dan & Ikan dan \\
pengganggu & lumut & lumut & lumut \\
Jumlah & 19 & 20 & 19 \\
Nilai Skor & 50 & 52 & 50 \\
Keterangan & Cukup & Cukup & Cukup \\
& sesuai & Sesuai & Sesuai \\
\hline
\end{tabular}

Sumber: Hasil Pengukuran

\section{Kecepatan Arus}

Pengukuran kecepatan arus dengan menggunakan current meter dimana hasil pengukuran memperlihatkan kecepatan yang bervariasi antara $5 \mathrm{~cm} / \mathrm{dtk}$ sampai 30 $\mathrm{cm} /$ dtk dengan nilai rata- rata untuk ketiga stasiun berkisar antara $15-20 \mathrm{~cm} / \mathrm{dtk}$. Kecepatan arus terendah berada pada stasiun II (Pulau Batanglampe), sedangkan kecepatan arus tertinggi berada terdapat pada stasiun I (Pulau Kambuno). Perbedaan kecepatan arus disebabkan oleh letak lokasi, adanya terumbu karang merupakan salah satu penyebab arus menjadi lemah, karena arus laut yang datang terhambat oleh barier yang dibentuk secara alami oleh terumbu karang. Pada saat yang lain adanya turbulensi dan perairan yang cukup terbuka, merupakan pendugaan lain terjadi perbedaan kuat arus. Wibisono (2005) mengatakan bahwa setiap proses aktivitas pasang maupun surut menimbulkan arus. Arus di laut dapat diakibatkan oleh tiupan angin atau pengaruh pasang surut, untuk perairan pantai umumnya didominasi oleh arus pasang surut yang dibangkitkan oleh tiupan angin.

Adapun di perairan Pulau Sembilan, saat pasang arus menuju ke utara, sebaliknya arah arus saat surut. Pada daerah laut terbuka (laut dalam) memperlihatkan arus menuju ke selatan, demikian pula pada selat antar pulau, arus berputar kearah selatan yang kemudian mengikuti pola ke utara di perairan bagian barat. Sehingga disimpulkan bahwa arus yang terjadi merupakan arus lokal akibat pasang-surut. Kecepatan arus berperan penting dalam perairan, misalnya, pencampuran masa air, pengangkutan unsur hara dan transportasi oksigen.

\section{Suhu Perairan}

Suhu perairan pada titik pengambilan sampel untuk budidaya rumput laut di perairan Pulau Sembilan diperoleh dengan menggunakan alat WQC (Water Quality Checker). Hasil pengukuran menunjukkan variasi sebaran suhu yang seragam di setiap pengukuran. Adapun hasil pengukuran suhu berkisar antara $28,7^{\circ} \mathrm{C}-\quad 32^{\circ} \mathrm{C}$. Suhu terendah di dapatkan pada stasiun III (Pulau Kodingare), sementara suhu tertinggi diperoleh pada stasiun I (Pulau Kambuno). Terjadinya perubahan suhu tidak terlepas dari pengaruh perubahan musim, pada awal penelitian yaitu bulan Juni suhu berkisar antara $28,7{ }^{\circ} \mathrm{C}-28,9^{\circ} \mathrm{C}$, sedangkan pada akhir penelitian yaitu bulan Oktober suhu berkisar antara $30{ }^{\circ} \mathrm{C}$ $32{ }^{\circ} \mathrm{C}$. Peningkatan suhu tidak terlepas dari pengaruh curah hujan yang berkurang.

Suhu perairan sangat penting dalam proses fotosintesis rumput laut, suhu air meskipun tidak berpengaruh mematikan namun dapat menghambat pertumbuhan rumput laut. Perbedaan temperatur air yang terlalu besar antara siang dan malam hari dapat mempengaruhi pertumbuhan, 
hal ini sering terjadi di perairan yang terlalu dangkal. Rumput laut mempunyai kisaran suhu yang spesifik karena adanya enzim pada rumput laut yang tidak dapat berfungsi pada suhu yang terlalu dingin maupun terlalu panas. Suhu perairan mempengaruhi laju fotosintesis dan dapat merusak enzim serta membran sel yang bersifat labil terhadap suhu yang tinggi. Pada suhu yang rendah, membran protein dan lemak dapat mengalami kerusakan akibat terbentuknya kristal di dalam sel, sehingga mempengaruhi kehidupan rumput laut, seperti: pertumbuhan dan perkembangan, reproduksi, fotosintesis dan respirasi (Laning, 1990 dalam Masita, 2007).

Secara umum rata-rata suhu di perairan Pulau Sembilan untuk budidaya Kappaphycus alvarezii, memperlihatkan nilai yang mendukung untuk kegiatan budidayamput laut.

\section{Kecerahan}

Kecerahan perairan di zona pemanfaatan budidaya rumput laut di perairan Pulau Sembilan berkisar antara 1,65 $\mathrm{m}$ hingga $6,50 \mathrm{~m}$ dengan rata-rata untuk semua stasiun berkisar antara 2,05 sampai dengan 6,09 m. Sebaran kecerahan tertinggi berada pada stasiun III yaitu Pulau Kodingare, sedangkan nilai kecerahan terendah berada pada stasiun I yaitu pada Pulau Kambuno. Adanya perbedaan kecerahann pada setiap lokasi pengambilan sampel berhubungan dengan kedalaman lokasi, substansi sedimen, kecepatan arus dan waktu dilakukannya pengamatan. Hutabarat (2000) mengatakan bahwa, cahaya akan semakin berkurang intensitasnya seiring dengan makin besar kedalaman. Pendugaan lain dari peneliti adalah adanya perbedaan waktu pengamatan yang dilakukan. Effendi (2003) yang mengatakan bahwa, pemantulan cahaya mempunyai intensitas yang bervariasi menurut sudut datang cahaya. Berdasarkan nilai rata-rata kecerahan pada perairan Pulau Sembilan memperlihatkan kisaran nilai yang masih dianjurkan dan dapat dilakukan budidaya rumput laut karna nilai yang dimiliki masuk dalam kategori sesuai berdasarkan matriks kesesuaian untuk budidaya rumput laut. Sementara untuk stasiun I dan stasiun III dapat dilakukan budidaya rumput laut karena nlai yang dimiliki masuk dalam kategori sedang berdasarkan matriks kesesuaian untuk budidaya rumput laut.

\section{Kedalaman Perairan}

Hasil pengukuran kedalaman perairan pada stasiun penelitian di perairan Pulau Sembilan berkisar antara $2 \mathrm{~m}$ sampai $10 \mathrm{~m}$ dengan nilai rata-rata yan bervariasi antara 4,25 sampai 6,25 m. Nilai kedalaman tertinggiberdasarkan nilai rata-rata terdapat pada stasiun II yaitu Pulau Batanglampe. Sedangkan nilai terendah berada pada stasiun I yaitu Pulau kambuno. Berdasarkan nilai yang ada pada tabel matriks kesesuaian untuk parameter kedalaman menunjukkan nilai yang sangat sesuai untuk budidaya rumut laut. Radiarta, $d k k$ (2004), mengkategorikan kedalaman 2-15 m dalam skor sangat sesuai 1-2 m dalam skor sesuai dan kedalaman lebih $<2$ atau $>15 \mathrm{~m}$ dalam skor kategori tidak sesuai. Berdasarkan nilai yang ada pada table matrik kesesuaian untuk nilai kedalaman menunjukkan nilaiyang sesuai untuk dilakukannya budidaya rumput laut.

\section{Material Dasar Perairan}

Hasil analisis terhadap material dasar/substrak pada ketiga stasiun penelitian di perairan Pulau Sembilan adalah karang berpasir dan pada stasiun Pulau Batanglampe dan Kodingare adalag substrat karang. Berdasarkan matriks kesesuaian substrak dasar perairan yang baik untuk lokasi budidaya rumput laut, maka ketiga stasiun penelitian masuk kedalam kategori sesuai. Ditjenkan (2009), substrak dasar yang cocok untuk budidaya rumput laut jenis Kappaphycus alvarezii adalah pasir dengan pecahan karang dan pasir kasar serta bebas dari lumpur.

\section{Salinitas Perairan}

Nilai salinitas yang diperoleh pada stasiun penelitian berkisar antara 30,0 ppt - 32,8 ppt dengan nilai rata-rata untuk ketiga stasiun berkisar antara 30,1 - 32,1 ppt. Kisaran nilai salinitas terendah berada pada stasiun I (Pulau Kambuno) sedangkan nilai salinitas teringgi terdapat pada stasiun II (Pulau Batanglampe). Perubahan salinitas dengan pola fluktuatif ditunjukkan dengan kisaran salinitas yang berbeda. Salinitas tertinggi dan terendah di setiap stasiun tidak terjadi pada stasiun yang sama setiap bulannya. Adanya perbedaaan kisaran salinitas disebabkan oleh beberapa faktor, seperti: Sirkulasi air, penguapan, curah hujan, dan aliran sungai.

Nilai salinitas yang diperoleh pada lokasi penelitian menunjukkan angka yang sesuai untuk dilakukan budidaya rumput laut tanpa harus diberikan faktor pembatas.

\section{Derajat Keasaman}

Hasil pengukuran diperoleh nilai derajat keasaman pada lokasi penelitian berfluktuasi yaitu 7,37 - 9,31 dengan pola sebaran $\mathrm{pH}$ yang variatif di perairan. $\mathrm{pH}$ tertinggi diperoleh pada stasiun III (Kodingare) yaitu 9,31 dan terendah pada stasiun I (Pulau Kambuno) yaitu 7,37.

Perbedaan nilai $\mathrm{pH}$ dalam perairan disebabkan oleh adanya perbedaan waktu pengukuran. Perubahan konsentrasi $\mathrm{pH}$ dalam perairan mempunyai siklus harian. Siklus ini merupakan fungsi dari karbondioksida. Effendi(2003) mengatakan bahwa, jika perairan mengandung kabondioksida bebas dan ion karbonat maka $\mathrm{pH}$ cenderung asam, dan $\mathrm{pH}$ akan kembali meningkat jika $\mathrm{CO} 2$ dan $\mathrm{HCO} 3$ mulai berkurang. Hasil penelitian memperlihatkan, adanya perbedaan $\mathrm{pH}$ pada tiap lokasi pengambilan sampel, tetapi secara keseluruhan nilai ratarata pada stasiun penelitian diperairan Pulau Sembilan berada pada kisaran yang mendukung untuk dilakukannya budidaya rumput laut. Hal ini sesuai pernyataan Anggadireja (2006) bahwa keasaman air (pH) yang cock untuk pertumbuhan rumput laut jenis Kappaphycus alvarezii umumnya berkisar antara 7 - 9, dengan kisaran optimum 7,3 - 8,2. Sedangakan menurut Sulistijo (2002), $\mathrm{pH}$ yang baik bagi pertumbuhan rumput laut adalah berkisar antara $6,8-9,6$.

\section{Oksigen Terlarut}

Hasil pengukuran secara in situ terhadap oksigen terlarut pada stasiun penelitian di perairan Pulau Sembilan berada pada kisaran 4,48 mg/l-11,08 mg/l. Konsentrasi tertinggi terdapat pada stasiun Pulau Kambuno pada bulan Agustus dan stasiun Pulau Batanglampe memiliki kadar terendah pada bulan Oktober. 
Berbedanya kandungan oksigen terlarut disebabkan karena adanya pergerakan dan percampuran massa air serta siklus harian variabel ini. Brotowidjoyo, $d k k$ (1995) mengatakan bahwa, pada kondisi perairan terbuka oksigen berada pada kondisi alami, sehingga jarang dijumpai kondisi perairan terbuka yang miskin oksigen.

Baku mutu DO untuk rumput laut adalah lebih dari 5 mg/l (Atmadja, $d k k$ 1996), hal ini berarti jika oksigen terlarut dalam perairan mencapai $5 \mathrm{mg} / \mathrm{l}$ maka metabolisme rumput laut dapat berjalan dengan optimal.

\section{Karbondioksida}

Konsentrasi kandungan $\mathrm{CO} 2$ selama lima bulan pengukuran menunjukkan pada kisaran 4-24 mg/l pada stasiun I (Pulau Kambuno), 4-16 mg/l pada stasiun II (Pulau Batanglampe) dan kisaran 2-36 mg/l pada stasiun II (Pulau Kodingare). Terjadinya peningkatan kandungan kandungan $\mathrm{CO} 2$ pada setiap stasiun kemungkinan disebabkan oleh tingginya laju respirasi oleh organisme perairan. Hal ini sesuai pernyataan Boyd (1990), menyatakan bahwa kandungan karbondioksida dalam air biasanya merupakan fungsi dari aktifitas biologi, dimana laju respirasi melebihi laju fotosintesis maka karbondioksida akan terakumulasi.

Karbondioksida di perairan sangat dibutuhkan oleh tumbuhan baik mikro maupun yang berukuran makro (tumbuhan tingkat tinggi) untuk proses fotosintesis. Meskipun memiliki peranan yang penting dalam perairan untuk kelangsungan hidup organisme air, namun kandungannya yang berlebihan dapat mengganggu bahkan menjadi racun bagi organisme di perairan (Kadi, 2005).

\section{Fosfat}

Hasil analisis kandungan ortofosfat dalam perairan pada awal penelitian yaitu bulan Juni hampir seragam pada semua stasiun yaitu $0,044 \mathrm{mg} / \mathrm{l}-0,063 \mathrm{mg} / \mathrm{l}$ dan meningkat pada bulan Agustus dengan kisaran 1,104 mg/l - 1,185 mg/l kecuali pada stasiun III (Pulau Kodingare) tidak memperlihatkan perbedaan yang signifikan. Selanjutnya kadar fosfat kembali turun pada akhir penelitian (bulan oktober) dan bahkan tidak terdeteksi. Tingginya curah hujan secara langsung membuat pengenceran di permukaan air laut sehingga kadar phosfat menjadi rendah. Peningkatan kadar fosfat pada akhir penelitian kemungkinan disebabkan oleh rendahnya curah hujan, selain itu diduga pengaruh adanya pengangkatan massa air dari dasar laut oleh proses upwelling telah mencapai pulaupulau Sembilan.

Adanya perbedaan kandungan fosfat juga diduga disebabkan oleh adanya bahan organik berupa limbah domestik (detergen), limbah pertanian atau pengikisan batuan fosfor oleh aliran air. Menurut Effendi (2003) mengatakan bahwa, sebagian besar fosfat berasal dari masukan bahan organik melalui darat berupa limbah industri maupun domestik (detergen). Hutabarat (2000), menyatakan bahwa sumber fosfat di perairan juga berasal dari proses pengikisan batuan di pantai. Kekurangan fosfat akan lebih kritis bagi tanaman aquatik termasuk tumbuhan alga, dibandingkan kekurangan nitrat di perairan. Di lain pihak walaupun fosfat dalam perairan berperan sebagai sebagai nutrien, akan tetapi tingginya kandungan fosfat di perairan dapat berdampak pada peledakan plankton.
Berdasarkan matriks kesesuaian budidaya kandungan fosfat pada ketiga stasiun penelitian yaitu Pulau Kambuno, Batanglampe dan Kodingare memperlihatkan kisaran yang cukup sesuai untuk mendukung kegiatan budidaya rumput laut Kappaphycus alvarezii.

\section{Nitrat}

Hasil pengukuran terhadap variabel nitrat memperlihatkan nilai yang bervariasi antara $0,046 \mathrm{mg} / \mathrm{l}$ $1,104 \mathrm{mg} / \mathrm{l}$ dengan nilai rata-rata sebesar 0,0126 mg/l-0,58 $\mathrm{mg} / \mathrm{l})$. Kandungan nitrat terendah terdapat pada Pulau Kambuno dan tertinggi terdapat pada stasiun Pulau Kodingare.

Kandungan nitrat pada stasiun penelitian menunjukkan fluktusi di setiap bulannya dengan variasi yang sangat signifikan, dengan kisaran yang sangat rendah hingga 0,146 mg/l. Konsentrasi tertinggi diperoleh pada bulan September pada stasiun Pulau Kambuno, demikian pula pada Pulau Batanglampe pada bulan September, lalu menurun signifikan pada bulan Oktober.

Perbedaan kandungan nitrat pada beberapa lokasi disebakan oleh tingginya nitrat di dasar perairan. Hutabarat (2000) bahwa konsentrasi nitrat akan semakin besar dengan bertambahnya kedalaman. Perbedan nilai rata-rata pada parameter nitrat disebabkan karena adanya pemukiman penduduk yang memungkinkan masuknya nitrat kedalam perairan. Effendi (2003) berpendapat bahwa, kadar nitrat dalam perairan banyak dipengaruhi oleh pencemaran antropogenik yang berasal dari aktifitas manusia maupun tinja hewan.

Kadar nitrat yang diperoleh pada stasiun penelitian di perairan Pulau Sembilan tergolong rendah. Berdasarkan nilai kandungan tersebut maka perairan dapat dikatakan sebagai perairan yang memiliki zat hara rendah (oligotrofik).

\section{Penentuan Lokasi Kesesuaian Budidaya Rumput Laut Kappaphycus alvarezii}

Penentuan daerah kesesuaian budidaya laut, mengacu pada matrik kesesuaian perairan yang disusun berdasarkan variabel primer, variabel sekunder dan variabel tersier. Ketiga variabel penyusun matrik kesesuaian tersebut merupakan variabel syarat, yang terdiri dari komponen variabel-variabel dalam parameter físika, kimia dan biologi.

Hasil evaluasi terhadap lokasi kesesuaian untuk budidaya rumput laut Kappaphycus alvarezii dengan mempergunakan kriteria pada Table 1, memperlihatkan perairan pulau Sembilan khususnya Pulau Kambuno, Pulau Batanglampe dan Pulau Kodingare berada pada kategori cukup sesuai (S2) untuk dilakukannya budidaya rumput laut jenis Kappaphycus alvarezii (Tabel 2). Variabel primer merupakan variabel yang perlu mendapat perhatian dalam usaha budidaya, dimana variable tersebut terdiri dari nitrat, fosfat, kedalaman, kecerahan perairan dan kecepatan arus. Fosfat merupakan unsur yang berperan dalam mendukung pertumbuhan dan perkembangan budidaya dalam pembentukan protein maupun aktivitas metabolisme. Pertumbuhan dapat tercapai dengan baik jika variabel ini tercukupi. Boyd (1990) dan Hutabarat (2000) mengatakan bahwa, fosfat merupakan unsur hara dalam perairan yang esensial untuk pertumbuhan Kappaphycus alvareziii. Namun walaupun unsur ini sangat penting bagi 
pertumbuhan Kappaphycus alvarezii tetapi pada kondisi berlebihan akan menyebakan peledakan mikroalga lainnya.

\section{KESIMPULAN}

Hasil penelitian maka dapat disimpulkan bahwa hasil identifikasi parameter físika, kimia dan biologi di perairan Pulau Sembilan menunjukkan nilai yang berbeda pada setiap stasiun. Namun hasil analisis kesesuaian perairan bagi pengembangan budidaya rumput laut Kappaphycus alvarezii di perairan pulau Sembilan khususnya Pulau Kambuno, Pulau Batanglampe dan Pulau Kodingare berada pada kategori cukup sesuai.

\section{DAFTAR PUSTAKA}

Atmadja, WS. A. Kadi, Sulistijo dan R. Satari. 1996. Pengenalan Jenis-Jenis Rumput Laut Indonesia. Puslitbang Oseanologi LIPI. Jakarta.

Anggadiredja, JT., A. Zatnika, H. Purwoto dan S. Istini. 2006. Rumput Laut. Penebar Swadaya, Jakarta.

Boyd, C.E. 1990. Water Quality in Ponds Fish for Aquaqulture. Alabama Agriculture. Aubum Universiy, Aubum.

Brotowijoyo M. D., Dj. Tribawono., dan E. Mulbyantoro. 1995. Pengantar Lingkungan Perairan dan Budidaya Air. Penerbit Liberty, Yogyakarta.

Ditjenkan Budidaya, 2009. Panduan Usaha Kebun Bibit Rumput Laut. Departemen Kelautan dan Perikanan. Jakarta.

Effendi, H. 2003. Telaah Kualitas Air Bagi Pengelolaan Sumberdaya Hayati Lingkungan Perairan. Kanisius.

Ghufron, M. H. Kordi. 2010. Marikultur Prinsip dan Praktek Budidaya Laut. Penerbit Andi Jogyakarta

Hutabarat, S. Dan S. M. Evans. 2000. Parameter Oseanografi. Universitas Indonesia Press. Jakarta.

Kadi, A. 2005. Kesesuaian Perairan Teluk Klabat Pulau Bangka untuk Lahan Budidaya Rumput Laut. Journal of Fisheries Science.

Nurdin, I.N. 2012.Evaluasi Mutu dan Penanganan Pascapanen Rumput Laut Eucheuma cottonii di Kabupaten Buton Provinsi Sulawesi Tenggara.Tesis Program Pasca Sarjana Fakultas Teknologi Pertanian Universitas Gadjah Mada.

Radiarta, I.N, Saputra, A. Dan Priono, B. 2004. Pemrtaan Kelayakan Lahan untuk Pengembangan Usaha Budidaya Laut di Teluk Saleh NTB. Jurnal Penelitian Perikanan Indonesia.

Rasyid. A. J. 2005. Studi Kondisi Fisika Oseanografi Untuk Kesesuaian Budidaya Rumput Laut Di Perairan Pantai Sinjai Timur. Jurnal Torani 15 : 73- 80.

Sujatmiko, W. Dan I.W. Angkasa. 2007. Teknik Budidaya Rumput Laut dengan Metode Tali Panjang. Direktorat Pengkajian Kehidupan. Badan Penerapan Pengkajian Teknologi (BPPT). Jakarta.

Sulistijo, 2002. Penelitian Budidaya Rumput Laut di Indonesia. Pusat Penelitian Oseanografi, Lembaga Ilmu Pengetahuan Indonesia. Jakarta.

Utojo, Mansur, A. Pirzan, A.M., Tarunamulia, Pantjara, B. 2004. Identifikasi Kelayakan Lokasi Lahan Budidaya Laut di Perairan Teluk Salleh Kabupaten Dompu NTB. Jurnal Penelitian Perikanan Indonesia.
Wibisono. 2005. Kesesuaian Budidaya Rumput Laut Berdasarkan Kapasitas Perairan Desa Arakan Kabupaten Minahasa Selatan. Jurnal Budidaya Perairan. 